\title{
1
}

\section{Does Out-Contracting of Welfare Services Promote Active Citizenship?}

\section{Karl Henrik Sivesind and Håkon Solbu Trætteberg}

\section{Introduction}

In the 1980s, Swedish welfare researchers travelled the world to present the Scandinavian social democratic model at conferences. The model represented a 'modern' alternative to the market economy and socialism, combining generous benefits and economic equality with high labour force participation for both women and men. However, the downside quickly became apparent: high taxes and swelling public debt. The transfer value to other countries was in question since the trend inspired by Thatcherism and Reaganomics was to cut taxes and slash public budgets. Was the model at all sustainable with an ageing population? But even as an economic crisis hit Scandinavia in the early 1990s, the welfare model did not die-it was transformed.

\footnotetext{
K.H. Sivesind $(\varangle) \cdot$ H.S. Trætteberg Institute for Social Research, Oslo, Norway e-mail: k.h.sivesind@socialresearch.no

H.S. Trætteberg e-mail: h.s.tratteberg@socialresearch.no 
In the new millennium, the Scandinavian countries-Denmark, Sweden and Norway-seemed to be on their way to overcoming at least some of the inherent problems of their welfare model. In a special issue in 2013, The Economist even presented the Nordic countries as 'the next supermodel' because they had reduced public debt and spending as shares of GDP, simplified and lowered taxes, and built pension systems on a solid foundation that made automatic adjustments for longer life expectancy, while at the same time developing open, innovative and knowledge-intensive economies. Furthermore, the Scandinavian countries have high levels of happiness and well-being (Helliwell et al. 2016) and social trust (Ervasti et al. 2008; Rothstein 2003) and navigated the 2008 global financial crisis better than almost everyone else. Norway had oil income invested in a sovereign fund and no public debt, but the other Scandinavian countries did not have such advantages. According to The Economist, there are compelling reasons to pay attention to these small countries on the edge of Europe: '... they have reached the future first. They are grappling with problems that other countries too will have to deal with in due course, such as what to do when you have reached the limits of big government and how to organize society when almost all women work. And the Nordic countries are coming up with highly innovative solutions that reject the tired orthodoxies of left and right'. Of particular interest is the fact that the Swedish public school system now has vouchers and for-profit schools competing with public schools. 'When it comes to choice, Milton Friedman [the neoliberal American economist] would be more at home in Stockholm than in Washington, DC', claimed The Economist.

Changes in the Swedish welfare model are indeed profound. In the early 90s, Sweden probably had the highest proportion of public welfare service employment of any of the West European countries. The nonprofit share was just 2\% (Lundström and Wijkström 1997; Sivesind and Selle 2010). This was a result of a huge political project to fight poverty and inequality by building the most modern welfare state in the world. Popular movements and voluntary organizations supported this venture, to a surprising degree also when it implied handing over their welfare service institutions to the state. The historian Lars Trägårdh claims Swedish people's home (folkhemmet) built on a social contract between what was perceived as a 
strong and good state and equal and autonomous individuals, liberating them from traditional, paternalistic and oppressive institutions-'the family, the neighborhood, the churches, the charity organizations' (2007, 27-28). But it was not all harmony, the large state was challenged from the conservative and communitarian critics, and even on the left-wing there was a concern that the citizens were becoming passive clients and that the state was unresponsive and bureaucratized. All groups argued for a stronger civil society (Trägårdh 2007).

Reforms intended to reduce the Swedish welfare state were implemented. First, from 1991 to 1994 , the conservative government gave the country's municipalities the opportunity to introduce competition and choice models. The social democratic government, from 1994 to 2006, did little to slow down this development. With the centre-right coalition, from 2006 to 2014, the reforms gained momentum again, in particular with the passing of a law on public procurement (Public Procurement Act, LOU 2007: 1091) and user choice (Freedom of Choice Act, LOV 2008: 962). Political reforms intended to empower individuals with the opportunity to choose welfare providers were introduced in more and more service areas, in combination with a more liberal system for approving new service institutions and no restrictions on extracting profits.

However, the expanding quasi-market for welfare services ultimately strengthened the profit-oriented welfare sector rather than civil society. State-funded welfare contracts in Sweden attracted private investments and venture capital, even from abroad. The welfare reforms stimulated strong commercial growth with a transformative effect. For-profit companies increased their number of employees from 90,000 to 236,000 between 2000 and 2013 and became 2.5 times larger. Their share of welfare employees rose from 9 to $19 \%$, while the nonprofit share remained extremely low, at 3\%, and the public sector share decreased from 88 to $78 \%$ (see Chap. 2). If the goal was to shrink the large welfare state, then the process was successful. However, perhaps unintentionally, private expansion to a large extent resulted in institutions owned by a small number of welfare conglomerates, with some of their owners situated in tax havens. What happened to the small, independent service units owned by local, responsible entrepreneurs, cooperatives or idea-based, nonprofit organisations? Sweden, the global exemplar for 
moderation, turned their welfare system completely around, from maximising public provision to welcoming international for-profit welfare investors (Henrekson and Jordahl 2012). Reforms signalled by the new centre-left minority coalition government in 2014 focused on counteracting some of the negative side effects of marketising welfare rather than stopping profit extraction. A widespread assumption seems to be that economic incentives are a necessary part of the restructuration process and that in any event, it is very difficult to stop the transfer of profits. Owners may not extract profits from year to year, but instead generate a surplus by buying and selling institutions or shares in welfare service units, or by paying more than market price for services or property rented from other companies they own. However, Sweden never seriously attempted to stimulate the expansion of the smallest nonprofit welfare sector in the EU, with the exception of former Eastern Bloc countries (Salamon and Sokolowski 2016). Massive goodwill from all political parties and a Compact (Överenskommelsen) between the Swedish Government and idea-based social organisations and service providers inspired by the UK were not enough (Johansson and Johansson 2012).

The legal establishment of user choice as a universal value, which is currently being introduced step by step in the Swedish welfare system, is just one example of old principles being sacrificed in order to improve the Scandinavian welfare system. Market mechanisms are being used in new ways to create progress in the welfare state. This was not part of the Scandinavian model promoted by welfare researchers in the 1980s as 'politics against markets' (Esping-Andersen 1985). Now, quasi-markets and tools inspired by New Public Management (NPM) have been widely implemented in all Scandinavian countries, but in slightly different ways (Kristiansen 2016). Surprisingly, this does not mean that the core welfare goals have been replaced. The policy documents still highlight deep-rooted Scandinavian ideals, such as public funding and regulation of core welfare services, decentralisation of governance, equal access for all to high quality services and the adaptation of services to user needs and preferences. However, there is also a willingness to innovate in order to better reach these goals. It is not always easy to see how 
market-emulating forms of governance can be the most suitable means to reach these goals. Maybe we are witnessing a change of welfare goals by means of governance reforms? When the role of the state changes from securing the equivalent quality of services for all to providing opportunities for choice, the responsibility for the results of the social policy shifts to the users, who make choices for themselves (Newman and Tonkens 2011). The Scandinavian eagerness in welfare reform results in large, rapidly evolving differences between the countries and between the service areas. In effect, Scandinavia has emerged as a laboratory for different welfare reform experiments; a proving ground for solving problems that other countries will also encounter in the future. The main approach in this book is therefore to compare the consequences of different forms of governance in three countries with shared welfare goals such as equivalent service quality and active citizenship.

The changes in Scandinavian welfare services based on public funding will be analysed in this book mainly by comparing the countries, service areas, and for-profit, nonprofit and public sectors. Each chapter will focus on different levels in the governance structure: laws and regulations at the national level, governance in municipalities and service institutions in elderly care and schools, and, finally, the consequences experienced by the users of the services. Which combinations of governance structures, service sector providers and user choice give the best results when it comes to promoting active citizenship? To set the stage for the following chapters, we will present the key service areas of schools and nursing homes and some of the key dilemmas facing Scandinavian welfare societies today; we will also describe how these issues will be analysed in this volume. To understand why it matters who provides welfare services, we use the concept of active citizenship active citizenship, which is subsequently explained. We then delve into theories about the fundamental differences between the public, nonprofit and for-profit sectors. Since we examine publicly financed welfare services, the institutional sectors will vary depending on how the state governs each service; therefore, it is also necessary to evaluate the role of the most important governance tools. Lastly, we give a brief overview of the different chapters in the book. 


\section{Comparing Service Areas and Sectors}

The special issue of The Economist that focused on Nordic countries was particularly concerned with the voucher system, which lets private schools compete with the public system. However, Sweden is emerging from an era marked by very strong public sector domination in its welfare provision and is, in fact, a latecomer among the Scandinavian countries when it comes to private alternatives and choice in education. In Denmark, $15 \%$ of students attend private schools in a user-choice system that has existed for 150 years. The free schools are nonprofit organisations that receive financial support from the government but have few legal restrictions on the educational content. Norway has a similar but less liberal system for nonprofit private schools. Only $7 \%$ of students in upper secondary education, and 3\% in lower secondary and primary education, attend private schools. In order to obtain public funding, these schools must offer alternative pedagogies or ideologies which are not offered by the public school system. However, at the same time, the core curriculum must be equivalent to that of public schools. In Sweden, teaching in private and public schools is subject to the same laws.

In other words, all three countries offer a type of voucher system and the right to choose private schools, instead of the public default option offered to all. The main difference is that in Sweden, for-profit businesses are allowed to run schools, while on paper there is less room for distinctive alternatives to the public system as there is in the other Scandinavian countries. This is the kind of 'experiments' that makes a Scandinavian comparison so interesting. The development of a Swedish system where 'Friedman would be at home', as The Economist put it, begs the question of whether this system is compatible with the ideals of a Scandinavian welfare model. Swedish school results, for median pupils as well as low and high performing pupils, have deteriorated more than any other country in OECD's PISA enquiry. Moreover, the difference between high and low performing students has increased: a troubling trend in light of the legal and normative foundations of the Scandinavian welfare model (Böhlmark and Holmlund 2012). This raises the question of whether better opportunities to choose schools have resulted in the 
separation of high and low performing pupils; and if so, whether this has had negative consequences for school results in general and for equal access to high quality education for all in particular. The social background has a very strong influence on how selective parents are, as well as their children's school results, and this may be the reason for increasing social differences in the Swedish voucher system. Perhaps the liberal free schools of Denmark or the more unitary school system of Norway, with fewer but more distinctive alternatives, is better suited to Scandinavian welfare ideals Put another way, what are the best methods for promoting active citizenship: nonprofit alternatives catering to special interests and needs, or competition over shares in a more standardised school market? The importance of governance, the roles and shares of the public, nonprofit and for-profit sectors for distinctive service profiles and active citizenship in compulsory schools, will be examined by Thøgersen and Trætteberg in this book's empirical chapters.

To obtain a contrast with schools, we will compare them with elderly care nursing homes, a service area that is also the responsibility of municipalities in all three Scandinavian countries. In this area, municipalities can decide to contract services out to commercial or nonprofit institutions, and the public administration generally has a much stronger influence over the allocation of users to service providers. Sweden has an increasing number of for-profit institutions, while Denmark has a long tradition of self-owning institutions, which are, in practice, nonprofit foundations. Norway not only has the most dominant public sector but also some traditional nonprofit providers owned by voluntary or religious foundations or associations. Recently, however, the country's nonprofit share has decreased while the for-profit share has grown (Statistics Norway 2016). All Scandinavian countries are moving away from the traditional framework agreements with private service providers, which would have been automatically renewed, and towards open tenders and user choice. Still, most municipal administrations are working hard to promote an equivalent quality of services to all users at all types of institutions. The use of quasi-markets and NPM tools has greatly expanded since the 1980s (Meagher and Szebehely 2013), as it has in other service areas. The question is whether this has changed the situation of users in relation to the institutions and municipalities. Since 
governance structures and the space for distinctive services are more limited in nursing homes for elderly care than they are in schools, we will compare the service areas to explore the consequences for users and their representatives. We can learn from such differences, not just those between countries but those between service areas as well.

The Scandinavian countries have chosen different tools of governance for influencing the mix of public, nonprofit and for-profit provisions. In general, quasi-markets with different combinations of competition, public certification and NPM-steering have become more widespread. However, Sweden has chosen what Ascoli and Ranci (2002, 6-9) would call a 'demand-based model', with user choice and simplified rules for the establishment of private services that can receive public funding. Norway has to a larger extent a 'supply-side model', with competition for public contracts occurring both within the public system and between public, nonprofit and for-profit providers. Denmark has a well-established but more liberal model of user choice, where local nonprofit alternatives flourish. At the same time, in all of the Scandinavian countries, citizenship rights and participation in the welfare field have been reinforced legally and through new best practices and professional standards (Rostgaard 2015).

\section{The Concept of Active Citizenship}

The balance between governance and user influence is critical in the Scandinavian welfare model. Services are not only influenced by voters through the electoral channel. The public administration and the welfare services it runs should also be directly responsive to affected citizens (Andersen and Hoff 2001; Petersson et al. 1989). When market-emulating tools of government have been implemented broadly and the dominance of the public sector in the service provision has been reduced or challenged, it is important to understand how different governance tools and types of providers affect the responsiveness of the institutions.

Historically, the Scandinavian social democratic approach to welfare has been that public dominance in all aspects of service provision is necessary in order to insulate citizens from the harmful effects of market 
forces. The public provision of services thus became a method for the collective creation of a new, democratic welfare society (Blomqvist 2004, 430; Sejersted 2011, 120-121). Indeed, the goal was to create services of such high quality that they would gain the support of citizens from all walks of life. Rothstein (1994) labelled this 'the high quality standardised solution': where nearly equal welfare services were allocated to all citizens via bureaucratic planning. This was not just important for reducing poverty and social inequality but was also considered crucial for the legitimacy of a system of welfare services funded by taxpayers.

In addition, the gradual establishment of citizens' rights meant that individuals were no longer forced to appeal for core services, but could demand them with some degree of authority. The combination of democratic control of services and strong citizens' rights are central aspects of what has been called a Scandinavian form of citizenship (Andersen and Hoff 2001; Hernes 1988). The decentralisation of influence is an essential tool used to reach the ideals of advanced social rights and equality. An implication of the decentralisation of influence is that it places decisions about service provision as close as possible to individuals and thus gives them influence over their own situations (Andersen and Hoff 2001).

On the input side, i.e. in the electoral democracy, important services such as care and education are a governmental responsibility. However, 'welfare municipalities' are in charge of important services that affect people's lives (Kröger 1997; Kjølsrød 2005; Loughlin et al. 2011, 11). Decisions about these services are made by local policy makers, who are closely connected to citizens. On the output side of the democratic process, Scandinavian citizenship entails that citizens who use services also have the power and right to influence the implementation of policies. This is where active citizenship is pursued: either collectively through user boards or individually when relatives of nursing home users seek to obtain a certain approach to care or parents request special follow-ups from their children's school.

Active citizenship is an analytic concept we use to examine the amount of control that citizens have over their everyday lives as users of public services. Their level of control is based on their citizenship role- the distribution of rights and obligations. To control their lives as users of 
public services, citizens need to have influence. More influence means more control, but absolute control can hardly occur in real life. If obligations are forced upon citizens who receive services, then this is the opposite of influence and entails a lack of control.

In the research literature, active citizenship is a contested concept with no shared definition. Different scholars have emphasised the issue of obligations in divergent ways. One approach sees active citizenship as 'a broad range of activities that promote and sustain democracy' (Hoskins $2014,14)$. These activities include political participation in formal politics, but also involve activities situated in the workplace, civil society and the private sphere (Hoskins and Mascherini 2009; Holford and van der Veen 2003). Furthermore, Newman and Tonkens (2011) emphasised increased obligations for users as an aspect of the agency of citizens, as they used the term active citizenship to explain why responsibilities for services are transferred from the state to the citizens. These obligations can take the form of care for oneself or for relatives; and in the quasi-market, citizens are expected to be market actors who influence the welfare sector by giving market incentives, like enter and exit, to providers.

For our specific purposes, we have developed a conception that enables us to evaluate whether the citizenship roles of users vary by type of service provider. In the chapter by Trætteberg, the operationalisation of active citizenship as it is used in the empirical analysis is further elaborated. Here, it is sufficient to present the definition and the main dimensions. Put briefly, the concept of active citizenship reflects three main actors involved in deciding the content of a public service when a citizen becomes a user: the user, the staff and the administrators and local politicians at the municipal level. The user can influence a public service by meeting with staff and institutional leaders or via changes obtained in interactions with leaders at the municipal level.

With this analytic concept, one can assess local political processes and governance of institutions as well as day-to-day interactions between users and staff members and collective forms of user control via user boards and related media. The concept of active citizenship thus brings attention to formal as well as informal ways of influencing services and, accordingly, the implementation of public policies. Active citizenship encompasses the activities users can engage in when assessing where to 
become users-at their institutions, in local policy processes and in their communities - in order to influence the service in question.

The active citizenship of users of public services is the ability citizens or their relatives have to actively control their own lives while being users of public services. Active control can be exercised prior to becoming a user or while being a user. Both choice and voice are important instruments for practicing active citizenship (Hirschman 1970). More specifically, in this book, three dimensions of active citizenship are used to analyse differences in the capacity for active citizenship for users-and their next of kin - of public, for-profit and nonprofit welfare services: choice, empowerment and participation.

With its three dimensions, active citizenship is an analytic perspective that enables us to measure aspects of users' experiences with welfare services. At the same time, it is an ideal type to which an empirical reality can be compared to see if high or low levels of active citizenship are observed along its three dimensions.

\section{Fundamental Sector Differences}

New tools in the governance of Scandinavian welfare may alter the relationship between the welfare states and their citizens as well as the composition of the welfare mix. By welfare mix, we refer to the division of public, nonprofit and for-profit providers in a service area. Often, the concept of the welfare mix also includes families or other informal providers, but this book focuses on publicly funded service institutions; and in Scandinavian welfare, this means that the focus is placed on professional providers. However, as we will see, families and relatives can be important contributors to these services as volunteers by exercising active citizenship together with or on behalf of the users. The importance of changes in the composition of the mix of welfare service providers depends on the substantive differences between different institutional sectors. Economic theories of nonprofit organisations try in principle to answer the question of why we need the third sector when we have a market and a state. In order to do this, these theories identify essential aspects of each of the institutional sectors and explain why and how they 
are different (Steinberg 2006; Salamon and Toepler 2015). These aspects are general, theoretical features of the institutional sectors and their relevance in a Scandinavian context varies according to how the states govern the providers in the different service areas. To understand the consequences of the use of particular governance tools and changes in the welfare mix, it is necessary to grasp the differences between institutional sectors at a general level.

A key expectation relates to creating a complete selection of service profiles for the population. Citizens are an increasingly diverse group with respect to culture, religion, ethnicity and so forth, and thus it is becoming increasingly difficult to create services tailored to individual citizens (Phillips and Smith 2011). Governments may lack the knowledge, capacity and coordinative ability to create a diverse enough system to cover the entire population. In addition, the public sector has a tendency to centre its attention on the median voter and majority groups in society and thus overlook the interests of marginal groups. For-profit providers offer services to the largest market segment, which is not so different from the public sector's emphasis on the median citizen. Consequently, there is a gap in services for minority populations: a gap the nonprofit sector is well suited to fill (Weisbrod 1978). By directing services toward smaller niches in the population, nonprofit compensate for the lack of breadth in public and for-profit providers' offerings in terms of quality, special needs, interests, methodology, ideology or beliefs (Smith and Grønbjerg 2006, 224; Clemens 2006). In Scandinavian countries, nonprofit welfare providers are funded by the state and are thus presumably vulnerable to the decisions of the majority. Yet, in the multi-party system, the minority groups catered to by at least some of the nonprofits are represented by parties who see nonprofits as their tool to provide services to their minority constituencies. In this way, nonprofits give breadth to the range of services while simultaneously being part of core services in some service areas.

In welfare services, great information asymmetry exists between providers and users. Users often have bad health, and the complexity of the services makes it impossible for one user to acquire the same expertise as professional providers. Therefore, the ability for users and society to trust providers is decisive (Hansmann 1980). The less information users have, 
the more important it is for them to be able to trust the service provider. This applies both to users and public regulators, as there are limited opportunities for monitoring the quality of this type of service (Evers et al. 1997). Weisbrod (1988) proposed distinguishing between quality indicators that are easy to observe and assess and those that are difficult to observe and assess. Different market participants have different incentives to prioritise the two different forms of quality. A profit-oriented provider typically has an incentive to achieve high measurable quality; but if doing so reduces profits, this same provider will have an incentive not to devote resources to having high unobservable quality (Hansmann 1987, 29). Nonprofit providers do not have the same disincentive to allocate resources to improve invisible quality (Salamon and Toepler 2015, 2168). In the Scandinavian context, Meagher and Szebehely (2013) have argued that tight regulation is a reason why increased plurality in the welfare mix in elderly care has led to limited differences in quality. As this volume demonstrates, however, conformity in quality limits the ability to achieve the supposed benefits of an expanded range of service content that would stem from plurality in the welfare mix. This demonstrates some of the difficult trade-offs authorities face when regulating the welfare mix.

The potential benefits of nonprofits when it comes to trust and broadening the scope of public services can help explain their functioning in the welfare mix. Yet, it is an all but universal Western phenomenon that the state shoulders the main responsibility for welfare but cooperates with nonprofit and for-profit providers in solving social and economic problems (Salamon and Toepler 2015, 2161). To understand the persistence of this phenomenon, Salamon (1987) developed the theory of interdependence. Its guiding principle is that each of the three sectors has strengths and weaknesses, with the strengths of one sector to some extent compensating for the weaknesses of another.

In spite of the supposed benefits of nonprofit provision, such providers also have some potential weaknesses that make them unsuitable as the only type of provider. Their central weakness is that they do not have sufficient growth capacity to produce all of the services people want. They do not have access to capital from investors, and they tend to focus on their care mission rather than on its expansion. Furthermore, the research literature holds that they are particularistic since they adapt their 
services to small groups and do not reach out to the whole population. Finally, they are accused of being paternalistic, providing services with a special vision for the community in mind rather than accommodating the visions of the users or of society at large (Salamon 1987).

For-profit providers complement the strengths and weaknesses of nonprofits. Their ability to quickly scale up to serve large portions of the population is highly valued by Scandinavian policy makers. This capacity has been particularly demonstrated in kindergartens in Norway as well as in many service areas in Sweden. Nevertheless, when left unmonitored, for-profits have potential weaknesses: They may produce too few of the services parts of the population needs. If the financing of providers is based on user payments, then their services may be priced at a level often too expensive for much of the population, thereby limiting access to them. In addition, as mentioned previously, they have public trust issues (Anheier 2005, 181-182).

The public sector aims to compensate for the failures of the for-profits. When for-profits do not provide enough of a service, the public sector can provide the service itself, as in the traditional Scandinavian model. To ensure affordable prices for the population, the government can pay for the service through voucher systems or subsidies. To remedy the lack of trust, public authorities can regulate the service and provide increased information flow to users (Steinberg 2006).

However, public authorities cannot fully compensate for the failures of the for-profits. The government tends to adapt the service it provides in-house to the median citizen. This makes the range of services inadequate for citizens who want a particular quality of service, or who, for various reasons, want a type of service content that differs from the majority's preferences. Furthermore, lack of trust is often based on key aspects of health and care services not being readily observable (Steinberg 2006). The government can thus encounter difficulties regulating something it does not know much about, rendering their efforts at best incomplete. These weaknesses of the state are addressed by nonprofits that cater to niche populations at the same time as their motivations provide different incentives from those of for-profits (Anheier 2005, 129_ 131). ${ }^{1}$ 
Consequently, the state pursues widespread cooperation with other providers in the welfare mix. Since the state cannot reach an optimal service level by providing all services in-house, and since nonprofit and for-profit providers are dependent on public financing and steering, the three sectors are interdependent. The theory of interdependence in the welfare provider mix has set the agenda for extensive research on the three institutional sectors and how they solve different tasks (Steinberg 2006). Much of the empirical work has been done thus far in an American context, where the relationship between the sectors is different from that of Scandinavia, in particular, when it comes to sources of funding. That said, the theory has a general scope, which suggests that the mechanisms it describes may also be active in a Scandinavian context.

\section{Governance Through Contracting or User Choice}

Because of the perceived differences between institutional sectors, most countries have policies to manage the composition of welfare service providers (Boris and Steuerle 2006; Lundbäck and Lundberg 2012). Yet, given that there are differences between public, for-profit and nonprofit providers, these differences are not static. Different contexts and conditions may increase or decrease differences.

How the Scandinavian context creates conditions that affect the prominence of these differences is a central theme in this book. This dynamic is based on the established literature, which holds that within a contractual regime with the public sector, nonpublic providers may lose much of their distinctiveness (Salamon and Toepler 2015, 2169; Toepler 2010; Salamon 2002). However, there is an important difference between supply-based and demand-based financing of nonpublic service providers (Ascoli and Ranci 2002, 6-9). Supply-based financing involves the privatisation of the provision of services. The idea is that the state wants to change how services are supplied to the public by transferring management responsibility from a public agency to a nonpublic entity. This form of financing makes small alterations in the relationship between citizens and providers, but enables the state to make demands of potential providers who are seeking to become suppliers of services. 
Demand-based financing means that the state wants to change the demand structure of the provision by enabling citizens to act as market customers by selecting their own providers. The changes sought from this type of financing are thus intended to influence providers by making changes in the relationship between citizens and providers.

Supply-based privatisation of the provision of services has a tendency to weaken nonpublic distinctiveness. Particularly, relevant examples are public tenders. This form of provider privatisation contributes to their commercialisation and promotes innovation related to management and organisation, not to the actual content of the service (Goodin 2003, 390-391). Tenders whereby nonprofit and for-profit providers compete on equal terms may lead the nonprofit to adapt the for-profit operational logic in order to remain competitive (Haugh and Kitson 2007).

Demand-based financing takes place when the users themselves choose an institution. As long as the public sector funds the service provider, it will be dependent on approval from public agencies; once this has been obtained, it can compete to attract users. Within this regime, market mechanisms to some extent replace public regulation. Since users are able to opt in and out of different institutions, it is not necessary for the government to impose the same level of regulation as it does when all users are forced to use the same institutions. The idea is that institutions whose services are not good enough will be uncompetitive and will thus be eliminated from the quasi-market. In this way, only institutions with an acceptable level of services remain, as the market does the job that the state must do when market forces are not allowed to function. This gives the different providers the increased ability to develop distinct characteristics as long as these are in accordance with users' preferences (Ascoli and Ranci 2002). Whether this happens depends on the heterogeneity of citizens' demands and the diversity of providers. For example, a multi-religious population can include schools which cater to different religious groups, each with their own distinct approach to school operations. Supply diversity is thus an empirical question for each context. 


\section{Outline of the Book and Its Chapters}

To answer the question about the importance of the use of market-emulating governance tools and changes in the mix of welfare service providers, we compare between countries; between nonprofit, for-profit and public sectors; and between schools and elderly care as different service and policy areas, each with different governance models. We focus on how different ways of organising services on different levels of the Scandinavian welfare system affect the users in order to reveal which factors may promote active citizenship. We have selected cases that will allow for comparison across the three analytic dimensions:

1. Country: Denmark, Sweden and Norway. Traditionally, within the Scandinavian model, Sweden and Norway have focused on strengthening the legal rights of citizens as users, while Denmark has in addition actively used nonprofit actors to enhance user choice as a tool for citizen empowerment (Andersen and Hoff 2001). Lately, there has been some convergence, as all countries have prioritised more user choice (Segaard 2015, and Chap. 3) despite more divergence in the composition of the welfare mix (Sivesind, this volume). Since 2000, Sweden has moved towards empowerment through marketisation, with a rapidly growing for-profit share in the welfare mix. In this way, one could say that the three Scandinavian countries currently have three different strategies when it comes to the promotion of active citizenship (Sivesind 2013, and Chap. 2). The three Scandinavian countries thus represent some interesting institutional differences regardless of similar welfare ideals. Methodologically, comparisons between the countries are useful for assessing under what circumstances the conclusions may have relevance.

2. Institutional sector: public, nonprofit and for-profit providers. Does it make a difference which of them provides services? It is still an open question whether traditional coordination by municipalities, reforms promoting user choice or marketisation is the best-suited means to achieve active citizenship. 
3. Service area: Schools and nursing homes. These two service areas are suitable for comparison since, as pointed out in the introduction, each has a different position in the Scandinavian welfare model. To compare them in light of the welfare mix and active citizenship is thus useful for understanding how changes in the former could potentially have different implications in different areas of the welfare model. At the same time, they are both core areas of municipal welfare services with different positions in the current political debate. The school sector is experiencing a conflict whereby liberal ideas about the rights of parents to choose schools with different content or better quality and to opt out of bad schools are challenging adherence to the 'unitary school', in which equality and social integration are given emphasis (Arnesen and Lundahl 2006). In the nursing home sector, the debate has focused less on variation in the content of care and more on the most efficient means to obtain sufficient care capacity with acceptable quality. In addition, the structure of governance is different. In schools, there is considerable national regulation with regard to the content of services (Helgøy and Homme 2006; Rönnberg 2014); while for elderly care, more of the decisions regarding the content of care are left to the municipalities (Vabo 2012).

What makes the Scandinavian countries particularly suitable for this kind of analysis is that they have similar welfare models and ideals but have chosen different governance tools to create changes. The welfare systems in the three countries are moving in such different directions that it resembles a natural experiment. This means that there are lessons to be learnt for other countries that are in the process of reshaping their welfare services while giving high priority to an active role for service users.

In the next two chapters of this book, we look into developments in these countries, sectors and service areas at the national level. In Chap. 2, Karl Henrik Sivesind analyses changes in shares of welfare service employment between the for-profit, nonprofit and public sectors on a national level in the three countries. The data are gleaned from national statistical agencies, public policy documents and studies of particular services in each of the Scandinavian countries. In Chap. 3, Signe Bock 
Segaard and Jo Saglie discuss the national legal and institutional framework within which local welfare services are provided: the relevant EU directives and their implementation, national policy instruments and national politics.

In Chaps. 4, 5 and 6, David Feltenius, Malene Thøgersen and Håkon Solbu Trætteberg analyse data from comparative case studies at the municipal level-where policies for schools and elderly care are implemented. Seven municipalities - three in Norway, two in Sweden and two in Denmark-were selected for matched case studies using similar data-gathering strategies and interview guides. The data come from three types of sources: interviews with users, staff and leaders at the institutions as well as the political and administrative leadership in the municipalities; local user surveys; and local strategic documents. In total, 27 institutions were studied in the seven municipalities. Within each municipality, two institutions were selected from each service area: one public and one nonpublic. For more information about the methodology used in these chapters, see the appendix to this chapter.

The chapters written by Feltenius and Thøgersen focus on governance in the municipalities and the service institutions in elderly care and schools, as well as the consequences for distinctive profiles and equivalent service quality. Chapter 4 by Feltenius analyses municipal governance of nursing homes, comparing the three Scandinavian countries in addition to in-house, public sector service providers and private service providers (nonprofit or for-profit) in the same municipalities. Chapter 5 by Thøgersen examines schools in a similar fashion. Chapter 6 by Trætteberg compares the two service areas, schools and nursing homes with regard to active citizenship. Trætteberg asks whether the manner in which services are governed and the institutional sector the service provider belongs to make a difference for users. Where do we find the most important differences: between the countries, between providers from different sectors or between the service areas? What are the causes for these differences?

In Chap. 7, Tord Skogedal Lindén, Audun Fladmoe and Dag Arne Christensen analyse Norwegian population surveys about user satisfaction in elderly care institutions, child care and primary schools in order to obtain a more generalisable view of the consequences for users of private 
and public service provisions. In the concluding chapter, Sivesind, Trætteberg and Saglie discuss the lessons that can be learnt from the 'natural experiments' in the welfare service provider mix, institutional contexts and governance tools in Scandinavian welfare services. These lessons may also be relevant for other countries facing similar social and economic challenges while pursuing goals of equal access to high quality services funded by the government.

\section{Appendix: Methods and Data Collection}

\section{Comparative Case Studies}

Since the same methodology and data are used in Chaps. 4, 5 and 6, a shared presentation follows. The data were collected in order to make comparisons across each of the analytic dimensions presented above. The institutions studied operate at the municipal level in each country under examination. The strategy was therefore based on selecting municipalities whereby pairs of public and nonpublic institutions could be compared within the same context.

Twenty-seven institutions were selected in seven municipalities: three municipalities in Norway, two in Sweden and two in Denmark. The most important criterion in the selection process was that the municipalities had providers from different institutional sectors in both nursing homes and schools. In order to obtain findings that were as robust as possible, we used a strategy incorporating a diverse selection of municipalities that was beneficial 'where different combinations of variables are assumed to have effects on an outcome' (Gerring 2008, 651). In this case, variations were assessed in terms of geographic location and the status of municipalities as either urban or rural. In addition, we considered the political leadership of each municipality and identified particular characteristics within the municipalities which were relevant to the study. Table 1.1 provides the main characteristics for each of the selected municipalities. Since municipalities cannot be selected in a way that standardises all relevant characteristics, there were some unavoidable idiosyncratic features of the municipalities under study that need to be 
Table 1.1 Characteristics of the selected municipalities

\begin{tabular}{|c|c|c|c|}
\hline Municipality & $\begin{array}{l}\text { Total number of } \\
\text { schools and } \\
\text { nursing homes }\end{array}$ & $\begin{array}{l}\text { Political affiliation } \\
\text { (at the time of data } \\
\text { collection) }\end{array}$ & $\begin{array}{l}\text { Relevant } \\
\text { characteristics }\end{array}$ \\
\hline \multicolumn{4}{|l|}{ Denmark } \\
\hline $\begin{array}{l}\text { Faaborg-Midtfyn } \\
\text { Population: } \\
\text { 50,953 (2015) }\end{array}$ & $\begin{array}{l}13 \text { public schools } \\
15 \text { nonprofit } \\
\text { schools } \\
10 \text { public nursing } \\
\text { homes } \\
1 \text { nonprofit } \\
\text { nursing home }\end{array}$ & $\begin{array}{l}\text { A social democratic } \\
\text { majority was in } \\
\text { power at the } \\
\text { beginning of the } \\
\text { data collection } \\
\text { period. After the } \\
2013 \text { elections, a } \\
\text { liberal-conservative } \\
\text { (Venstre) majority } \\
\text { came into power }\end{array}$ & $\begin{array}{l}\text { Faaborg-Midtfyn } \\
\text { is a rural } \\
\text { municipality } \\
\text { situated on the } \\
\text { island of Funen. } \\
\text { It stands out as a } \\
\text { municipality } \\
\text { with a large } \\
\text { share of students } \\
\text { attending } \\
\text { nonprofit } \\
\text { schools (29\%) }\end{array}$ \\
\hline $\begin{array}{l}\text { Herning } \\
\text { Population: } \\
86,864 \text { (2015) }\end{array}$ & $\begin{array}{l}31 \text { public schools } \\
8 \text { nonprofit } \\
\text { schools } \\
10 \text { public nursing } \\
\text { homes } \\
5 \text { nonprofit } \\
\text { nursing homes }\end{array}$ & $\begin{array}{l}\text { Liberal-conservative } \\
\text { (Venstre) } \\
\text { throughout the } \\
\text { data collection } \\
\text { period }\end{array}$ & $\begin{array}{l}\text { Herning is a small } \\
\text { town located in } \\
\text { Jutland whose } \\
\text { borders } \\
\text { encompass a } \\
\text { large geographic } \\
\text { area } \\
\text { Herning has a } \\
\text { large number of } \\
\text { nonprofit nursing } \\
\text { homes }\end{array}$ \\
\hline \multicolumn{4}{|l|}{ Sweden } \\
\hline $\begin{array}{l}\text { Östersund } \\
\text { Population: } \\
59,485 \text { (2012) }\end{array}$ & $\begin{array}{l}35 \text { primary } \\
\text { schools, } 4 \text { of which } \\
\text { are private ( } 2 \\
\text { for-profit, } 2 \\
\text { nonprofit) } \\
22 \text { nursing homes, } \\
15 \text { of which are } \\
\text { public and } 7 \text { of } \\
\text { which are } \\
\text { for-profit. } \\
\text { Östersund has a } \\
\text { municipal policy } \\
\text { that } 25 \% \text { of } \\
\text { nursing homes }\end{array}$ & $\begin{array}{l}\text { Social democratic } \\
\text { majority }\end{array}$ & $\begin{array}{l}\text { Östersund consists } \\
\text { of a small town } \\
\text { and surrounding } \\
\text { rural area that } \\
\text { covers a large } \\
\text { geographical } \\
\text { region. It is } \\
\text { located in } \\
\text { northern } \\
\text { Sweden }\end{array}$ \\
\hline
\end{tabular}


Table 1.1 (continued)

\begin{tabular}{|c|c|c|c|}
\hline Municipality & $\begin{array}{l}\text { Total number of } \\
\text { schools and } \\
\text { nursing homes }\end{array}$ & $\begin{array}{l}\text { Political affiliation } \\
\text { (at the time of data } \\
\text { collection) }\end{array}$ & $\begin{array}{l}\text { Relevant } \\
\text { characteristics }\end{array}$ \\
\hline $\begin{array}{l}\text { Sollentuna } \\
\text { Population: } \\
66,859 \text { (2012) }\end{array}$ & $\begin{array}{l}\text { should be run by } \\
\text { non-public } \\
\text { providers } \\
36 \text { primary } \\
\text { schools, } 17 \text { of } \\
\text { which are private } \\
\text { (only } 2 \text { are } \\
\text { nonprofit; the } \\
\text { rest are for-profit). } \\
27 \% \text { of the } \\
\text { students in private } \\
\text { schools } \\
10 \text { nursing homes, } \\
7 \text { of which are } \\
\text { for-profit and } 3 \text { of } \\
\text { which are public. } \\
\text { The public nursing } \\
\text { homes are run by } \\
\text { a publicly owned } \\
\text { company that is } \\
\text { intended to } \\
\text { function as a } \\
\text { private unit }\end{array}$ & $\begin{array}{l}\text { The town's mayor is } \\
\text { affiliated with the } \\
\text { Conservative Party, } \\
\text { leading a } \\
\text { centre-right } \\
\text { majority in the city } \\
\text { council }\end{array}$ & $\begin{array}{l}\text { Sollentuna is one } \\
\text { of the } \\
\text { municipalities in } \\
\text { Sweden that has } \\
\text { gone the } \\
\text { furthest towards } \\
\text { introducing } \\
\text { market } \\
\text { mechanisms in } \\
\text { the care sector } \\
\text { and adheres } \\
\text { strictly to an } \\
\text { ordering- } \\
\text { performing } \\
\text { model } \\
\text { Sollentuna is a } \\
\text { suburb of } \\
\text { Stockholm, } \\
\text { Sweden's capital } \\
\text { city }\end{array}$ \\
\hline $\begin{array}{l}\text { Norway } \\
\text { Asker } \\
\text { Population: } \\
60,106 \text { (2016) }\end{array}$ & $\begin{array}{l}24 \text { public schools } \\
3 \text { nonprofit } \\
\text { schools } \\
4 \text { public nursing } \\
\text { homes } \\
1 \text { for-profit } \\
\text { nursing home }\end{array}$ & Conservative majority & $\begin{array}{l}\text { Asker is a wealthy } \\
\text { municipality in } \\
\text { the suburbs of } \\
\text { Oslo, Norway's } \\
\text { capital city. } \\
\text { Asker is one of } \\
\text { the first } \\
\text { Norwegian } \\
\text { municipalities to } \\
\text { have a for-profit } \\
\text { nursing home }\end{array}$ \\
\hline
\end{tabular}


Table 1.1 (continued)

\begin{tabular}{|c|c|c|c|}
\hline Municipality & $\begin{array}{l}\text { Total number of } \\
\text { schools and } \\
\text { nursing homes }\end{array}$ & $\begin{array}{l}\text { Political affiliation } \\
\text { (at the time of data } \\
\text { collection) }\end{array}$ & $\begin{array}{l}\text { Relevant } \\
\text { characteristics }\end{array}$ \\
\hline $\begin{array}{l}\text { Steinkjer } \\
\text { Population: } \\
21,781 \text { (2016) }\end{array}$ & $\begin{array}{l}12 \text { public schools } \\
1 \text { nonprofit } \\
\text { school } \\
3 \text { public nursing } \\
\text { homes } \\
1 \text { nonprofit } \\
\text { nursing home }\end{array}$ & Centre-left coalition & $\begin{array}{l}\text { Steinkjer consists } \\
\text { of a small town } \\
\text { and surrounding } \\
\text { rural area that } \\
\text { covers a large } \\
\text { geographic } \\
\text { region. It is } \\
\text { located in the } \\
\text { Trøndelag region } \\
\text { of central } \\
\text { Norway }\end{array}$ \\
\hline $\begin{array}{l}\text { Løten } \\
\text { Population: } 7588 \\
\text { (2016) }\end{array}$ & $\begin{array}{l}5 \text { public schools } \\
1 \text { nonprofit } \\
\text { school } \\
1 \text { public nursing } \\
\text { home that was not } \\
\text { included in this } \\
\text { study }\end{array}$ & Labour Party majority & $\begin{array}{l}\text { Løten is a rural } \\
\text { municipality } \\
\text { with no variation } \\
\text { in terms of the } \\
\text { nursing home } \\
\text { sector; therefore, } \\
\text { only schools } \\
\text { were } \\
\text { investigated }\end{array}$ \\
\hline
\end{tabular}

reported. The column labelled 'Relevant characteristics' presents idiosyncratic information for each municipality.

Within each municipality, we applied the matching case design strategy (Dunning 2010, 289-290). We selected two institutions from each service area: one public and one nonpublic. These institutions are complex organisations comprising a number of attributes that can together produce a given outcome. Therefore, we tried to minimise diversity between the selected institutions in each of the municipalities. In order to achieve a control effect for such attributes to better grasp variations stemming from the service sector, we limited diversity in terms 
Table 1.2 Selected municipalities and institutional sectors of the non-public institutions

\begin{tabular}{llll}
\hline Country & Municipality & Nursing home & School \\
\hline Denmark & Faaborg-Midtfyn & $\begin{array}{c}\text { Nonprofit and } \\
\text { public } \\
\text { Nonprofit and } \\
\text { public } \\
\text { Sweden }\end{array}$ & Nonprofit and public \\
public & Östersund & $\begin{array}{c}\text { For-profit and public } \\
\text { For-profit and } \\
\text { public }\end{array}$ & $\begin{array}{c}\text { public } \\
\text { For-profit and public }\end{array}$ \\
Norway & Sollentuna & $\begin{array}{c}\text { For-profit and } \\
\text { public } \\
\text { Nonprofit and } \\
\text { public } \\
\text { N/A }\end{array}$ & Nonprofit and public \\
& Steinkjer & Nonprofit and public \\
\hline
\end{tabular}

of size, the socioeconomic circumstances of users and geographic location. Obviously, in real life, no two institutions are sufficiently similar to achieve complete control, something we consider in the qualitative case analysis. Table 1.2 lists the municipalities and institutional sectors of the selected institutions.

\section{Data Collection}

The data were derived from three types of sources: (1) interviews with users, staff and leaders at the institutions as well as interviews with the political and administrative leadership of the municipalities; (2) local user surveys; and (3) local strategic documents. Before collecting the data, we developed a field guide that specified which sources of data were relevant. The field guide detailed what kinds of documents and local user surveys should be collected and analysed, as well as who to interview. It also contained interview guides that were used to conduct semi-structured interviews with all groups of interviewees. When appropriate, one could add extra questions in each country.

In all cases, the interviews were conducted with one or two administrative leaders in the municipalities and with one or two political leaders. Because of this, we were not always able to cover the whole range 
of political views, but we nonetheless tried to select key informants with the best insights about the institutions from the perspective of the municipality. In all cases, we interviewed the leader of the institutions in question. From the staff, we selected the safety representative or leader of the local union. This was done in order to avoid self-selection, i.e. that the leader of the institution could pick who our interviewees should be and was based on the expectation that these staff members would be more informed than the average colleague. To gauge user opinions, we formed focus groups with either part of the user boards or the user boards as a whole. We tried to take into account that these users, by virtue of their seat on the user board, potentially had more personal resources than the average user. It must also be pointed out that the user boards in nursing homes mostly consisted of the users' relatives, not the users themselves. The same situation occurred in the investigated schools, where parents constituted the majority of users on the user boards. In some instances, people who the case study revealed to have potentially interesting perspectives were also interviewed. For example, the leader of the council for the elderly in one municipality was interviewed, as was the leader of a municipal-level council for school parents in another municipality. In total, we conducted 35 interviews in Denmark, 21 in Sweden and 57 in Norway.

Local user surveys were conducted by the municipalities. They were designed differently for each municipality and some municipalities did not have them at all. They are therefore not useful for making comparisons between municipalities; but in some instances, they are useful for making comparisons within municipalities. The surveys were thus not only used for procuring background information prior to conducting interviews, but also served as an independent source of information about user views. This is the only data source for Chaps. 4-6 where the opinions of a large number of users are represented. The substantial survey material used in Chap. 7 thus complements the approach taken in Chaps. 4-6.

The local strategy and policy documents include documents covering municipal policies pertaining to the service areas or general approaches to user influence. In addition, we obtained the corresponding documents at the welfare institutions. Not all of the institutions had formal steering 
documents; but when they did, this information was used to triangulate interview data and user surveys. In the analysis, concurrence between different sources gave robustness to the observations, while divergence between different sources indicated that further investigation was needed, for example, by including specific questions about contested topics in the interviews.

\section{Note}

1. Studies from Norway have shown that, generally, volunteer organisations enjoy more trust in the population than their public sector or for-profit counterparts (Wollebæk et al. 2000, Fig. 2-11).

\section{References}

Andersen, Jørgen Goul, and Jens Villiam Hoff. 2001. Democracy and citizenship in Scandinavia. New York: Palgrave Macmillan.

Anheier, Helmut K. 2005. Nonprofit organizations. Theory, management, policy. Oxon: Routledge Milton Parks.

Arnesen, Anne-Lise, and Lisbeth Lundahl. 2006. Still social and democratic? Inclusive education policies in the Nordic welfare states. Scandinavian Journal of Educational Research 50 (3): 285-300.

Ascoli, Ugo, and Costanzo Ranci. 2002. The Context of new social policy in Europe. In Dilemmas of the welfare mix. The new structure of welfare in an era of privatization, eds. Ugo Ascoli and Costanzo Ranci, 1-24. New York: Kluwer Academic/Plenum Publishers.

Blomqvist, Paula. 2004. The choice revolution: Privatization of Swedish welfare services in the 1990s. Social Policy \& Administration 38 (2): 139-155.

Böhlmark, Anders, and Helena Holmlund. 2012. Lika möjligheter? Familjebakgrund och skolprestationer 1988-2010. Institutet för arbetsmarknads_och utbildningspolitisk utvärdering (IFAU): Uppsala.

Boris, Elizabeth T., and C. Eugine Steuerle. 2006. Nonprofits \& government: Collaboration \& conflict. Washington, DC: Urban Institute Press.

Clemens, Elisabeth S. 2006. The constitution of citizens: Political theories of nonprofit organizations. In The nonprofit sector: A research handbook, eds. 
Walter W. Powell and Richard Steinberg. New Haven, Conn.: Yale University Press.

Dunning, Thad. 2010. Design-based inference: Beyond the pitfalls of regression analysis? In Rethinking social inquiry: Diverse tools, shared standards, eds. David Collier and Henry E. Brady, 273-312. Lanham, Md: Rowman \& Littlefield. Ervasti, Heikki, Torben Fridberg, Mikael Hjerm, and Kristen Ringdal. 2008. Nordic social attitudes in a European perspective. Cheltenham: Edward Elgar. Esping-Andersen, Gøsta. 1985. Politics against markets. The social democratic road to power. Princeton, NJ: Princeton University Press.

Evers, Adalbert, Riitta Haverinen, Kai Leichsenring, and Gerald Wistow. 1997. Developing quality in personal social services. Concepts, cases and comments. European Centre Vienna: Ashgate.

Gerring, John. 2008. Case selection for case-study analysis: Qualitative and quantitative techniques. In The Oxford handbook of political methodology, eds. Janet M. Box-Steffensmeier, Henry E. Brady, and David Collier, 645-684. Oxford: Oxford University Press.

Goodin, Robert E. 2003. Democratic accountability: The distinctiveness of the third sector. European Journal of Sociology 44 (03): 359-396.

Hansmann, Henry. 1980. The role of nonprofit enterprise. Yale law journal 89 (5): 835-901.

- 1987. Economic theories of nonprofit organization. In The Nonprofit Sector: A Research Handbook. The Independent Sector: A Research Handbook, ed. Walter W. Powell, 27-42. New Haven: Yale University Press.

Haugh, Helen, and Michael Kitson. 2007. The third way and the third sector: New labour's economic policy and the social economy. Cambridge journal of economics 31 (6): 973-994.

Helgøy, Ingrid, and Anne Homme. 2006. Policy tools and institutional change: Comparing education policies in Norway, Sweden and England. Journal of Public Policy 26 (02): 141-165.

Helliwell, John F., Richard Layard, and Jeffrey D. Sachs. 2016. World happiness report, update, vol. I. New York: Sustainable Development Solutions Network. Henrekson, Magnus, and Henrik Jordahl. 2012. Vinster och privatiseringar i landet Lagom. Respons 1 (2): 12-18.

Hernes, Helga M. 1988. Scandinavian citizenship. Acta Sociologica 31 (3): 199215.

Hirschman, Albert O. 1970. Exit, voice, and loyalty: Responses to decline in firms, organizations, and states. Cambridge, MA: Harvard University Press.

Holford, John, and Ruud van der Veen. 2003. Lifelong learning, governance and active citizenship in Europe. Brussels: European Commission Project HPSE-CT-1999-00012. 
Hoskins, Bryony L. 2014. Active citizenship. In Encyclopedia of quality of life and well-being research, ed. Alex C Michalos, 14-16. Springer Netherlands. Hoskins, Bryony L., and Massimiliano Mascherini. 2009. Measuring active citizenship through the development of a composite indicator. Social Indicators Research 90 (3): 459-488. doi: 10.1007/s11205-008-9271-2.

Johansson, Håkan, and Mairon Johansson. 2012. From a 'Liberal' to a 'Social democratic' welfare state: The translation of the english compact into a Swedish context. Nonprofit Policy Forum 3 (2). doi:10.1515/2154-3348.1057. Kjølsrød, Lise. 2005. En tjenesteintens velferdsstat. In Det norske samfunn, eds. Ivar Frønes and Lise Kjølsrød, 184-209. Oslo: Gyldendal akademisk.

Kristiansen, Mads Bøge. 2016. One scandinavian approach to management by objectives and results? Scandinavian Journal of Public Administration 20 (1): 45-70.

Kröger, Teppo. 1997. Local government in Scandinavia: Autonomous or integrated into the welfare state? In Social care services: The key to the Scandinavian welfare model, ed. Jorma Sipilä, 95-108. Avebury: Aldershot. Loughlin, John, Frank Hendriks, and Aanders Lidström. 2011. Introduction. In The Oxford handbook of local and regional democracy in Europe, eds. John Loughlin, Frank Hendriks, and Aanders Lidström. Oxford: Oxford University Press.

Lundbäck, Mattias, and Anders Lundberg. 2012. Varför är det så få idéburna organisationer $i$ välfärden?. Stockholm: Tillväxtverket.

Lundström, Tommy, and Filip Wijkström. 1997. The nonprofit sector in Sweden, The Johns Hopkins nonprofit sector series. Manchester: Manchester University Press.

Meagher, Gabrielle, and Marta Szebehely, eds. 2013. Four Nordic countriesfour responses to the international trend of marketisation. In Marketisation in Nordic eldercare: A research report on legislation, oversight, extent and consequences, eds. Gabrielle Meagher and Marta Szebehely, Stockholm: Department of Social Work, Stockholm University.

Newman, Janet, and Evelien Tonkens. 2011. Participation, responsibility and choice: Summoning the active citizen in western European welfare states. Amsterdam: Amsterdam University Press.

Petersson, Olof, Anders Westholm, and Göran Blomberg. 1989. Medborgarnas makt. Stockholm: Carlssons.

Phillips, Susan D., and Steven Rathgeb Smith. 2011. Between governance and regulation. Evolving government-third sector relationships. In Governance 
and regulation in the third sector: International perspectives, eds. Susan D. Phillips and Steven Rathgeb Smith. New York: Routledge.

Rönnberg, Linda. 2014. Justifying the need for control. Motives for Swedish national school inspection during two governments. Scandinavian Journal of Educational Research 58 (4): 385-399.

Rostgaard, Tine. 2015. Nar fortiden er langere end fremtiden. Stockholm Nordens Välfärdscenter.

Rothstein, Bo. 1994. Vad bör staten göra. Stockholm SNS Förlag.

Rothstein, Bo. 2003. Introduction: Social capital in Scandinavia. Scandinavian Political Studies 26 (1).

Salamon, Lester M. 1987. Of market failure, voluntary failure, and third-party government: Toward a theory of government-nonprofit relations in the modern welfare state. Nonprofit and Voluntary Sector Quarterly 16 (1-2): $29-49$.

Salamon, Lester M. 2002. The Tools of government: A guide to the new governance. New York: Oxford University Press.

Salamon, Lester M, and Stefan Toepler. 2015. Government-Nonprofit cooperation: Anomaly or necessity? VOLUNTAS: International Journal of Voluntary and Nonprofit Organizations 26 (6): 2155-2177.

Salamon, Lester M., and S. Wojciech Sokolowski. 2016. The size and scope of the European third sector. Brussels: European Union FP7 (grant agreement 613034). Third Sector Impact.

Segaard, Signe Bock. 2015. Skole og eldreomsorg i Skandinavia. Nasjonale foringer for ikke-offentlige aktører. Oslo: Institutt for samfunnsforskning.

Sejersted, Francis. 2011. The age of social democracy Norway and Sweden in the Twentieth Century. Princeton: Princton University Press.

Sivesind, Karl Henrik. 2013. Ideella välfärdstjänster: en lösning på den skandinaviska modellens framtida utmaningar? In Civilsambället klämt mellan stat och kapital. Välfärd, mångfold, framtid, eds. Lars Trägårdh, Per Selle, Lars Skov Henriksen and Hanna Hallin, 75-88. Stockholm: SNS Förlag.

Sivesind, Karl Henrik, and Per Selle. 2010. Civil society in the Nordic countries: Between displacement and vitality. In Nordic associations in a European perspective, eds. Risto Alapuro and Henrik Stenius, 89-120. Baden-Baden: Nomos Verlagsgesellschaft.

Smith, Steven Rathgeb, and Kristen A. Grønbjerg. 2006. Scope and theory of government-nonprofit relations. In The nonprofit sector: A research handbook, eds. Walter W. Powell and Richard Steinberg, 221-242. New Haven, Conn: Yale University Press. 
Statistics Norway. 2016. Table: 09929: Institutions for the aged and disabled, by ownership. www.ssb.no/pleie.

Steinberg, Richard 2006. Economic theories of nonprofit organizations. In The nonprofit sector: A research handbook, eds. Walter W. Powell and Richard Steinberg, 117-139. New Haven, Conn: Yale University Press.

Toepler, Stefan. 2010. Government funding policies. In Handbook of research on nonprofit economics and management, eds. Bruce Seaman and Dennis $\mathrm{R}$ Young, 320-334. Cheltenham: Edward Elgar.

Trägårdh, Lars. 2007. The 'civil society' debate in Sweden: The welfare state challenged. In State and civil society in Northern Europe. The Swedish model reconsidered, ed. Lars Trägårdh, 9-36. New York: Berghahn Books.

Vabo, Signy Irene. 2012. Tiltakende statlig styring av kommunesektoren-også på eldreområdet? In Det norske flernivådemokratiet, eds. Marit Reitan, Jo Saglie, and Eivind Smith, 97-135. Oslo: Abstrakt.

Weisbrod, Burton Allen. 1978. The voluntary nonprofit sector: An economic analysis. Lexington, MA: Lexington Books.

Weisbrod, Burton Allen. 1988. The nonprofit economy. Mass: Harvard University Press.

Wollebæk, Dag, Per Selle, and Håkon Lorentzen. 2000. Frivillig innsats: Sosial integrasjon, demokrati og økonomi. Bergen: Fagbokforlaget.

\section{Authors' Biography}

Karl Henrik Sivesind is Research Professor at the Institute for Social Research, Oslo, Norway. He is currently manager of the project 'Conditions and Impacts of Welfare Mix' funded by the Norwegian Research Council, and he is leader for Work Package 'Elaboration and Testing of Impact Indicators' on the project 'Third Sector Impact-The Contribution of the Third Sector to Europe's Socio-economic Development' funded by the EU's 7th Framework Programme. He has studied changes affecting civil society by analysing data from population surveys and local association surveys as a part of the activities of Centre for Research on Civil Society and Voluntary Sector in Oslo/Bergen. He has also been involved in several comparative research projects about the nonprofit sector and welfare services. 
Håkon Solbu Træetteberg is a senior research fellow at the Institute for Social Research, Oslo, Norway. His main research interest is publicly-funded welfare services in general and the importance of the welfare mix in particular. Trætteberg received his Ph.D. in 2016, partly on work presented in this book.

Open Access This chapter is licensed under the terms of the Creative Commons Attribution 4.0 International License (http://creativecommons.org/licenses/by/ $4.0 /$ ), which permits use, sharing, adaptation, distribution and reproduction in any medium or format, as long as you give appropriate credit to the original author(s) and the source, provide a link to the Creative Commons license and indicate if changes were made.

The images or other third party material in this chapter are included in the chapter's Creative Commons license, unless indicated otherwise in a credit line to the material. If material is not included in the chapter's Creative Commons license and your intended use is not permitted by statutory regulation or exceeds the permitted use, you will need to obtain permission directly from the copyright holder.

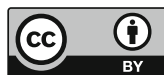

